\title{
The Influence of Marketing Intelligence on Business Competitive Advantage (A Study of Diamond Bank Plc)
}

\author{
- Ladipo Patric Kunle Ade, Awoniyi Mufutau Akanbi, Arebi Ismail \\ Tubosun
}

\begin{abstract}
This study investigates the influence of Marketing Intelligence on Business Competitive Advantage: A study of Diamond Bank Plc, Nigeria. Five objectives were identified and translated into five research questions which aptly answered by subjecting them to a test of hypotheses. A Descriptive research was used to survey 292 members of the staff of Diamond Bank in Lagos, Central Regional branches and head office. Out of which 285 responses were obtained, while 6 responses were destroyed because they were not properly filled. Also, data was collected through a self-administered questionnaire, as Pearson correlation, T-test and Regression were used to test the hypotheses statements. However, the result of the findings revealed that marketing intelligence sub-constructs such as internal records, competitor's sales data, marketplace opportunity, competitors' threats and competitors' risks have significant and positive influence on business competitive advantage. Thus, it can be concluded that marketing intelligence as sensitive information has enabled the bank to successfully acquire more profit, expand the branch network all over the country, perform better than its rivals in the market and increase its business competitive advantage.
\end{abstract}

Keywords: Marketing Intelligence, Business Competitive Advantage, Internal Records, Competitor's Sales Data, Marketplace Opportunity, Competitors' Threats, Competitors' Risks.

JEL Classification: L14, L25, M31, M38

\section{INTRODUCTION}

Today, the wave of the changes in the business world is developing, in which no doubt the marketing intelligence is its base. Organizations are confronted with different environmental changes. These changes take place so fast that, if organizations do not prepare themselves, their survival will be in danger. Marketing intelligence is to prevent the astonishments and the employees' inability against environmental changes and to reduce and minimize the company's exposure to danger (Johns \& Van Doren, 2010). A new apparatus which helps the organizations to reach a suitable place in today's environment is the use of marketing intelligence. The concept of intelligence is marketing information that is considered as an ongoing effort to increase the competitive ability of the strategic programming processes. Marketing intelligence is the systematic collection and analysis of publicly available information about consumers, competitors, and developments in the marketplace (Kotler \& Armstrong, 2013). 
Igbaekemen(2014) noted that, successful companies take an outside-inside view of their business. He recognize that marketing environment is constantly presenting new opportunities and threats, which can only be detected, collected, analyzed and utilized through the use of marketing intelligence and likewise an 'organization' should understand the importance of continuously monitoring and adapting to that environment. Many organizations fail to see change as opportunity. They ignore or resist changes until it is too late. Their strategies, structures, systems and organizational cultures grow increasingly obsolete and dysfunctional.

(Igbaekemen, 2014) added that many factors have increased the need for more and better marketing intelligence as companies become national and international in scope, they need more information on larger, more distant markets as income increases and buyers become more selective Therefore, marketing intelligence is important since the quality of the marketing information affects the effectiveness of decision making in the banking sector, there is always a rivalry among the various players in the banking sector, and each bank needs to device means of existing, sustaining and becoming a mega force to be reckoned with in this sector. This research will provide better information for organizations, particularly banking industry in Nigeria, about how customers pay interest in their variety of products, appeals, cost data, market data and competitor's sales.

\section{OBJECTIVE OF THE STUDY}

The major objective of this research is to examine the influence of marketing intelligence on business competitive advantage. However, minor objectives of this study are as follows:

1. To determine the relationship between internal record and business competitive advantage.

2. To investigate the relationship between competitor's sales data and business competitive advantage.

3. To examine whether marketplace opportunity influences business competitive advantage.

4. To determine whether competitor's threat influences business competitive advantage.

5. To investigate whether competitive risk influences business competitive advantage.

\section{RESEARCH QUESTIONS}

1. What is the relationship between internal record and business competitive advantage?

2. What is the relationship between competitor's sales data and business competitive advantage?

3. Does marketplace opportunity influence business competitive advantage?

4. Will competitor's threat influence business competitive advantage?

5. Does competitive risk influence business competitive advantage? 


\section{RESEARCH HYPOTHESES}

This is a statement proposing the directionality of relationship between marketing intelligence and business competitive advantage. It is a tentative statement that is subjective to verification. Thus, the hypotheses for this research work are as follows:

$\mathrm{HO}_{1}$ : There is no significant relationship between internal record and business competitive advantage.

$\mathrm{HO}_{2}$ : There is no significant relationship between competitor's sales data and business competitive advantage.

$\mathrm{HO}_{3}$ : Marketplace opportunity does not significantly influence business competitive advantage.

$\mathrm{HO}_{4}$ : Competitor's threat does not significantly influence business competitive advantage.

$\mathrm{HO}_{5}$ : Competitive risk does not significantly influence business competitive advantage.

\section{LITERATURE REVIEW}

\subsection{Theoretical Framework}

The theoretical underpinnings of this study are schema theory, congruence theory and resources based view theory. The first theory discussed in this paper is a schema theory which is based on the idea that humans use a categorical approach to organize and structure information contained in memory. A schema is an "abstract or generic knowledge structure, stored in memory that specifies the defining features and relevant attributes of some stimulus domain, and the interrelations among these attributes" (Crocker, 1984). Schemas can be developed through exposure to or experience of a stimulus domain (e.g., a situation, person, or object) and are believed to guide perception, thought and action of consumers in subsequent instances (Speck, et al. 1988; McDaniel 1999). From the marketing intelligence perspective, schema and congruence theory aid the thorough, categorizing and systematic collection of vital information that is likely useful for the organisation from the customers as well as the competitors. This information is centered on various reasons relating to organization, product, price, promotion and distribution. However, the congruence of information will foster the category under which information with similar facts should be put. This is based on similarities, relevance and importance of information. Meanwhile, the new information collected from customers and competitors may be similar to the existing information. Therefore, in order to incorporate the schema information into organisation data base, information congruence is an appropriate approach to categorize information for effective decision, action, and assimilation or to serve as alternative if the information is severe.

Also, resources-based view is the second theory discussed in this paper, which explains how marketing intelligence as information could serve as resources to an organization. Ray et al (2004) distinguished between tangible and intangible resources and posited that intangible resources such as information are often the most important ones from a strategic point of view. They argue that intangible resources are more likely to be a source of sustained competitive advantage 
rather than tangible ones. Priem and Butler (2003) confirmed that one of the most influential articles ever published is Wernerfelt's 1984 contribution entitled 'A Resource-Based View of the Firm'. In addition to Porter's concept of five forces in designing strategy (Porter 1980), the article opens ground for various strategy writers towards sustainable competitive edge, as the aim of many organizations. Therefore, as managers strive to gain competitive edge, an environment where organizational optimum performance can be increased should be arranged.

\subsection{Empirical Review}

The growth of internet has prompted online marketing intelligence activities; this was explained according to Alamsyah, Rahmahand Irawan (2015) to determine sentiment analysis based on appraisal theory for marketing intelligence in Indonesia's mobile phone market using Bahasa Indonesia to compare positive and negative sentiments of popular smart phone products in Indonesia, which are Lumia and Xperia. After the calculation was performed based on target and appraisal related in sentences and tweets levels, the results reveal that Lumia have more positive results than Xperia.

Also, the study conducted by Freihat (2012) reveals the relationship between the major components of marketing information system, and the decision-making in Jordanian shareholding medicines production companies. In the study, 56 marketing managers and marketing information system working staff were selected from 7 companies. The finding reveals that there is a statistically significant relationship between internal records, marketing research, marketing intelligence and decision-making. Therefore, the study suggested that, regular and continuous training programs in and out of the company must be conducted for the marketing information system companies employees in the areas of collecting, processing and manipulating of data, in order to benefit from the experiences of others, exchange of experiences, expand their knowledge, and increase their competences in the performance of their jobs.

Similarly, Alhadid, Al-Zu'biand Samer (2015) in their study conducted to investigate the relationship between marketing the information system and gaining competitive advantage in the banking sector in Jordan. Secondary data was obtained from documented sources and primary data from the use of a questionnaire. The results of the analysis showed that there is a relationship between the major components of marketing information system like internal records, marketing research, and marketing intelligence towards achieving a competitive advantage in the Jordan Banking sector. The results also indicated that only two traits; age and educational level, had a relationship with marketing information system. However, there was no significant relationship between gender, experience years of respondents and their perceptions of marketing information system. Therefore, marketing intelligence explores the usefulness of the use of information technology in achieving competitive advantage.

According to Venter and Rensburg (2014) in their study conducted to determine the relationship between marketing intelligence and strategic marketing in South African organizations. In the study, a quantitative survey was used among 166 South African marketing decision-makers. The finding shows that the availability of various categories of marketing intelligence has an indirect effect on strategic marketing. 
Igbaekemen (2014) investigates the influence of marketing intelligence as a strategic tool in achieving or attaining competitive edge'. In the study, the problems of competition was addressed, marketing intelligence and the adoption of suitable marketing intelligence system for an organization becomes imperative. The impact of competition in the business environment has compelled many organizations to turn around and start scanning the environment for information, so as to have competitive edge over other similar organization within the industry.

Hakkak and Ghodsi (2015) in their research conducted to introduce competitive advantage as well as to assess the impacts of the balanced scorecard as a means to measure the performance of organizations. 120 employees of the organizations affiliated to the social security department in North Khorasan Province were selected as the participants in the research. And the results indicated that there is a significant and positive impact of the implementation of the balanced scorecard on the sustainable competitive advantage. Therefore, the organizations should show a high level of significance and sensitivity toward their clients and customers so that they will be satisfied and have a good interaction with the organization.

\subsection{Conceptual Framework}

\subsubsection{Concept of Marketing Intelligence}

Marketing intelligence as Igbaekemen(2014) explained is everyday information about development in the marketing environment that helps managers prepare and adjust marketing plans. The marketing intelligence system determines the intelligence needed and collecting same by searching the environment and deliver to the marketing manager who needs it. Marketing intelligence comes from diverse sources such as: the company's personnel executives, engineers and scientist, purchasing agents and the sales force. But, company people are often busy and fail to pass on important function. The Company must sell its people on their importance as intelligence gathers, to spot new development and urge them to report intelligence back to the organization. Sometimes, in wide networking companies, the intelligence information is usually contracted to external agents or suppliers and at the extreme level 'hidden hackers' to break and capture for the company all relevant information from their competitors for their effective utilization. However, marketing intelligence as an organizational strategy can perfectly work for a company as well against the company. Therefore, organizations must act fast and take every necessary step towards protecting themselves from the snooping of competitors.

\subsubsection{Internal Records}

Internal records is an aspect of marketing intelligence that handle information about an organization operation system, sales data, core competence and other strategies which include their strength, weakness, opportunities and threat. Internal records are the data collected and stored in a database which pertains to daily marketing activities. The information technological changes are stored in a company's database and only the assigned member of the internal control unit has the relevant access to such information based on its sensitivity. The term 'database' as an internal record contains information about prospective customers which stored in a computer with software to process the information. A significant technological innovation is database marketing, the collection and use of individual customer- specific information to make marketing more efficient. Computer technology provides the ability to pull apart and recombine 
information in ways previously impossible but which presently permit the company to identify customers who are more predisposed to their products and to whom they can direct their marketing efforts. This, however, is one of the objectives of marketing intelligence (Igbaekemen, 2014). It helps in planning so as to minimize the risk of uncertainty about the future. Marketers use marketing intelligence for gathering and evaluating internal and external data during processing phase, which later are used for evaluation through a management tool called SWOT Analysis (Tan \& Ahmad, 1999).Therefore, banks or organizations that are able to secure their database from getting hacked by external agents or competitors and work on their information effectively will have competitive edge over others in the same industry that are unable to secure their internal records in a proper way. The competitive edge in this regard, enables results to be higher in one company than another, in such areas as productivity, profitability, market share and effectiveness, for a given firm competing in the same industry.

\subsubsection{Competitors' Sales Data}

Competitor's sales data is another component of marketing intelligence which could also influence the competitive edge of an organization over another. Sales data is very sensitive as the information can create competitions in the market settings. Sales data serve as a guide to firms in identifying their strength towards increasing their sales volume in the market; it also helps to identify weaknesses in some parts of the market where an adjustment is needed to be made. In a segmented market where the market is saturated with many competitors, an organization needs to access their sales data on day-to-day basis in order to boost their sales over their competitors in the market. The example of Big-Cola in Nigerian market that came with a larger quantity of cola drinks under which increase in their sales record were used as a strategy to strengthen up and improve management confidence, through market segmentation to take over the market as other competitors pretended not to have been sleeping. Meanwhile, competitors' sales data as a sensitive information could trigger or gear up the market competitors to stand on their toes and act as fast as possible before their market will be taking from them. Many organizations keep their sales information safe only for them to build their strength on, while on the other hand, this information could be useful for the competing firms to know how their rivals are doing in order for them to take the right strategy to outwit them in the market. However, competitor's sales data is information that covers sales records of a firm on a routine basis in a competitive market. Such information is stored in the organization database which has been recorded by salespeople on their devices from the field to keep the company's sales transactions as well as their competitors. Therefore, any bank or firm in the market settings that is able to identify this gap and make an effective use of it as an opportunity will have a competitive edge over others in the market which will tend to increase sales volume, market share, organizational profitability, productivity and effectiveness.

\subsubsection{Marketplace Opportunity}

A marketplace opportunity according to Nwokah and Onduku (2009) is a strategy which is concerned with creating and realizing new market place opportunities. Opportunities define new ways of creating and developing value for customers: new products or solutions; extending existing product lines, reconfiguring existing solutions. Also, Fahey (2007) noted that "the executive team continuously addresses two types of new marketing opportunities: 
1. Extending current opportunities: How can we extend opportunities that are the focus of our current strategy?

2. Potential marketplace opportunities: What opportunities beyond the reach of our current strategy should we be considering? What opportunities may be lurking but not yet fully evident in market place change?"

Under the first opportunity as indicated above, short-term opportunities often centre on identifying ways to modify the current strategy to add value for customers (Fahey, 2007). He added using three industries as an example to highlight how intelligence created assessments leading to new opportunities to extend and leverage the current strategy two key exchanges must occur between strategy and intelligence professionals: First, the executive team must 'challenge' the intelligence team to identify and develop the contours of new opportunities. Second, the intelligence team must demonstrate that it is fully committed to learning about the firm's strategy.

However, Nwokah and Onduku (2009) explained these exchanges as the framework for identifying and shaping the extension of current opportunities under the first strategy, and the second strategy input is the potential market place opportunities. He added that the executive team needs to develop strategy where possible, that will be a winner strategy for the future.

\subsubsection{Competitors' Threat}

In threats, opportunities would be much easier to realize where it is not for the presence of current and potential competitors. Fahey (2007) identified competitors' threats as "ways that a rival can inhibit a company's strategy from succeeding in the market place". Nwokah and Onduku (2009) added that "if threats are lately detected, resources tied up in supporting a strategy may be substantially wasted, as strategy can be adapted to eliminate, ameliorate or avoid the threat". They, therefore, stated the following questions that the executives should pose:

1. "How might competitors most adversely affect our current strategy?

2. Which competitors are most likely to do so?

3. How might we best "handle' these threats?"

This shows how effective information could serve in an organization's current and future plan. Every organization that sees the future from today and plays away the threat from the competitors in the market settings will have a competitive edge over others. The marketing intelligence unit must, therefore, assess current and potential competitor change for its strategy implications for threats. And also, the executive team must be alerted to current or potential competitors' threats (Nwokah and Onduku, 2009).

\subsubsection{Competitive Risk}

Competitive risk as a component of marketing intelligence is a strategy, and strategy is played over time in a marketplace or competitive context that extends even beyond competitors. "Change in and around the market place (being driven by customers, channels, suppliers, governmental agencies, technology houses, political parties, etc.) is the source not only of marketing opportunities and competitors' threats but of competitive risks" (Nwokah and Onduku, 2009). The competitive risks include any marketplace change that could negatively affects the firm's current 
or potential strategy" (Fahey, 2007). Fahey, 2007 supplied the three questions an executive team should always pose to its intelligence team under competitive risk:

1. "What competitive risks does our strategy face?

2. What competitive risks might we face in the future?

3. How can we best manage these risks? “

In order to provide answer to these three questions stated above which seek to compels the intelligence team to extend their perception beyond the competitive trends, patterns and discontinuities to isolate and assess risks and demonstrate how they negatively affects the pursuit of specific opportunities (Nwokah and Onduku, 2009). However, one of the top priorities of an organization is to take advantage of product quality tailored towards satisfying their customers and the assessment of the environment. The issue of marketing intelligence is as important as these top priorities. The negligence of information in a competitive market could endanger an organization to fold-up unexpectedly. Competitive risk as a component of marketing intelligence needs more attention which required intelligence specialist to handle. Most successful organizations in the competitive market valued the power and opportunities behind information either for current or future purposes. These firms frequently assess their strategies, environments and changes in technology. Any organization that failed to do this will experience a negative effect of its current or potential strategy on the organization performance. Therefore, competitive risk as an important aspect of marketing intelligence is a strategy which every organization competing in the local or global market should take into consideration based on its influence in gaining competitive advantage towards achieving an organization's long term objective and survival in the marketplace.

\subsubsection{Business Competitive Advantage}

Business competitive advantage explains the core strategy or unique resources by which an organization sources and utilizes the same to achieve better results than the competitors in the marketplace. According to Chern, Anthony and Chih-Ping (2014) in Igbaekemen (2014), firms competing in a given target market, at any point in time, differ in their objectives and resources, others are strapped for funds, some are old and established while others are new and fresh, some strive for rapid market share growth, while others strive for long term profits. He further stated that firms occupy different competitive position in the target market. In this study, the business competitive strategies adopted in Nigerian banking industry to which Diamond Bank belongs will be evaluated. This is based on the roles firms in this industry play in the target market which includes; leading, following or niching and challenging. However, every industry market leader is the firm in the industry with the largest market share. It usually leads other firms in price changes, new product introduction, distribution coverage and promotion spending. Market leaders use several defense strategies of maintaining their position and prevent followers or challengers from talking over, such as; defense, pre-empire defense, counter offensive, mobile defense and contraction defense. The market leader dictates the price and other market activities, while market challenger is a runner-up firm in an industry that is fighting hard to increase its market share. Also, a market follower is a runner-up firm in the industry that wants to hold its share without rocking the boat, as market nicher is a firm in an industry that serves small segments that other 
firms overlook or ignore. Competitive advantage can be reflected in overall core competence in essential marketing function.

\subsection{Conceptual Model}

In light of the foregoing, the study uses the model below to provide a further insight as to the web of relationships between marketing intelligence and business competitive advantage.

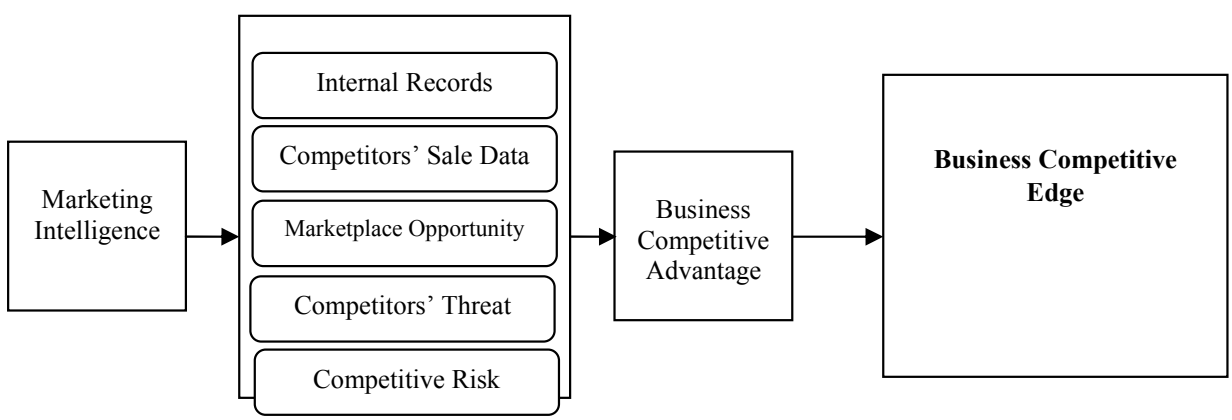

Fig. 1 - Model of Marketing Intelligence and Business Competitive Edge. Source: Conceptualized by the Researcher, 2016

Figure 1 above shows the relationship between marketing intelligence and business competitive advantage. The implication of the model as represented in the figure is that a web of relationship exists among the components of marketing intelligence previously explained above like internal record, competitors sales data, marketplace opportunity, competitors threat, and competitive risk, on business competitive advantage like profitability, sales turnover, market share, productivity and effectiveness.

\section{RESEARCH METHODOLOGY}

\subsection{Research Design}

A descriptive research design using cross-sectional survey method was adopted for a use in this study. A descriptive research design involves the field enquiries by collecting data using questionnaire or interview from the target population at a period of time. Therefore, the design was considered as the most appropriate for this study because the variables of the research are purely descriptive and can only be examined through primary data collection. The data generated were then analyzed along with the research hypotheses leading to appropriate inferences and generalizations.

\subsection{Sampling and Data Collection Procedure}

The data collection which was facilitated through the cross-sectional survey made use of a structured questionnaire administered to 1,081 population of Diamond Bank staff in Lagos Central Regional branches and Lagos Victoria Island headquarter. Using Yamane (1967) formula, a total 
sample size of 292 was adopted and Bowley (1926) proportional allocation formula was used to ensure that the sample represent the appropriate unit regardless of their population size. Therefore, a stratified random sampling technique was used to divide the sample size into twelve homogenous groups according to the branches and the head office.

\subsection{Study Instruments}

A research instrument is a device for collecting relevant data or measuring the variables which are used for answering research question and/or testing study hypothesis (Dixon-Ogbechi, 2002). The study made use of a structured and self-administered questionnaire. The questionnaire was divided into two sections. The first section was developed based on the objective of the research, while the second section captures demographic characteristics of the respondents, such as sex, age, position, experience and highest academic qualifications. Also, a pilot study was conducted to test the accuracy and the consistency of the research instrument. For the purpose of the study, a data collection instrument was subjected to content, construct and face validity; the result of the reliability test (in variables) obtained from the SPSS following a pilot study is presented in the table below.

Tab. 1 - Reliability Test of Variables (Source: Pilot Study, 2016)

\begin{tabular}{|l|l|c|c|c|}
\hline No & Variables & N & Items & Cronbach Alpha \\
\hline 1 & Internal Record & 40 & 6 & .971 \\
\hline 2 & Competitor's Sale Data & 40 & 5 & .952 \\
\hline 3 & Marketplace Opportunity & 40 & 6 & .972 \\
\hline 4 & Competitive Threat & 40 & 6 & .851 \\
\hline 5 & Competitive Risk & 40 & 5 & .929 \\
\hline 6 & Business Competitive Advantage & 40 & 6 & .922 \\
\hline
\end{tabular}

As shown in the Table 3, internal record as the first variable with 6 items reveals Cronbach alpha coefficient of $0.971(\mathrm{~N}=40)$, competitor's sales data with 5 items measures $0.952(\mathrm{~N}=$ 40), marketplace opportunity with 6 items measures $0.972(\mathrm{~N}=40)$, competitive threat with 6 items measures $0.851(\mathrm{~N}=40)$, competitive risk with 5 items measures $0.929(\mathrm{~N}=40)$, while the dependent variable business competitive advantage with 6 items measures $0.922(\mathrm{~N}=40)$. However, as explained in the work of Pallant (2001) when a Cronbach alpha coefficient value is above 0.7 , the scale is reliable and/or has a reliable internal consistency. Therefore, all the scale items of the above six variables are strongly reliable and acceptable.

\subsection{Procedure for Data Analyses}

Data were statistically analyzed after being collected from the field. The descriptive statistics was used for the analysis. The data generated from the field of study will be presented with simple tables and for the purpose of the data analysis; both descriptive and inferential statistical techniques were used. The frequency distribution and percentage were used to describe the aspect of the data, where all the data will be presented in forms of tabulation, frequency and percentages. In addition to this, hypotheses were tested through the Pearson Correlation and Multiple Re- 
gression Analysis as the main statistical tools that explained the relationship between variables under parametric test.

\section{DATA ANALYSIS}

The results of the data analyzed for the study were presented on the basis of the hypotheses generated for the study.

\section{Hypothesis One}

$\mathrm{HO}_{1}$ : There is no significant relationship between internal record and business competitive advantage.

Tab. 2 - Relationship between Internal Records and Business Competitive Advantage. Source: Research Study, 2016

\begin{tabular}{|c|l|c|c|}
\hline \multicolumn{4}{|c|}{ Correlations } \\
\hline \multirow{2}{*}{ SPSS Output } & Internal Records & $\begin{array}{c}\text { Business Competitive } \\
\text { Advantage }\end{array}$ \\
\hline \multirow{4}{*}{\begin{tabular}{c} 
Internal Records \\
\cline { 2 - 4 }
\end{tabular}} & Pearson Correlation & 1 & $.968^{* *}$ \\
\cline { 2 - 4 } & Sig. (2-tailed) & & .000 \\
\cline { 2 - 4 } $\begin{array}{c}\text { Business Competi- } \\
\text { tive Advantage }\end{array}$ & $\mathrm{N}$ & 279 & 279 \\
\cline { 2 - 4 } & Searson Correlation & $.968^{* *}$ & 1 \\
\cline { 2 - 4 } & $\mathrm{N}$ & .000 & 279 \\
\hline & $* *$. Correlation is significant at 0.05 level (2-tailed). \\
\hline
\end{tabular}

The table showed the result of the hypothesis stated above. To test the hypothesis, the Pearson correlation coefficient was carried out to show the relationship between internal records and business competitive advantage. The relationship between the two variables produced a positive correlation coefficient of $0.968^{* *}$ which depicted a strong direct correlation between internal records and business competitive advantage. Also, the two-tailed test conducted to check the significance level of the value of correlation coefficient yields a P-value of 0.000 which was significant at 0.05 level. Therefore, the hypothesis that states there is no significant relationship between internal record and business competitive advantage was rejected, as the result implied that internal record was significantly related to business competitive advantage.

\section{Hypothesis Two}

$\mathrm{HO}_{2}$ : There is no significant relationship between competitors' sales data and business competitive advantage. 
Tab. 3 - Relationship between Competitors' Sales Data and Business Competitive Advantage. Source:Research Study, 2016

\begin{tabular}{|c|l|c|c|}
\hline \multicolumn{4}{|c|}{ Correlations } \\
\hline \multirow{2}{*}{ SPSS Output } & $\begin{array}{c}\text { Competitors' } \\
\text { Sales Data }\end{array}$ & $\begin{array}{c}\text { Business Competitive } \\
\text { Advantage }\end{array}$ \\
\hline \multirow{3}{*}{\begin{tabular}{c} 
Competitors' Sales Data \\
\cline { 2 - 4 } $\begin{array}{c}\text { Business Competitive } \\
\text { Advantage }\end{array}$
\end{tabular}} & Pearson Correlation & 1 & $.975^{* *}$ \\
\cline { 2 - 4 } & Sig. (2-tailed) & 279 & .000 \\
\cline { 2 - 4 } & Pearson Correlation & $.975^{* *}$ & 279 \\
\cline { 2 - 4 } & Sig. (2-tailed) & .000 & 1 \\
\cline { 2 - 4 } & N & 279 & 279 \\
\hline \multicolumn{2}{|c|}{$* *$ Correlation is significant at 0.05 level (2-tailed). } \\
\hline
\end{tabular}

The table showed the result of the hypothesis stated above. To test the hypothesis, the Pearson correlation coefficient was done to show the relationship between competitors' sales data and business competitive advantage. The relationship between the two variables produced a positive correlation coefficient of $0.975^{* *}$ which depicts a strong direct correlation between competitors' sales data and business competitive advantage. Also, the two-tailed test conducted to check the significance level of the value of correlation coefficient yields a P-value of 0.000 which was significant at 0.05 level. Therefore, the hypothesis that states there is no significant relationship between competitors' sales data and business competitive advantage was rejected, as the result implies that competitors' sales data is significantly related to business competitive advantage.

\section{Hypothesis Three}

$\mathrm{HO}_{3}$ : Marketplace opportunity does not significantly influence business competitive advantage.

Tab. 4 - Relationship between Marketplace Opportunity and Business Competitive Advantage. Source: Research Study, 2016

\begin{tabular}{|c|c|c|c|}
\hline \multicolumn{4}{|c|}{ Correlations } \\
\hline \multicolumn{2}{|c|}{ SPSS Output } & \multirow{2}{*}{$\begin{array}{c}\text { Marketplace Opportunity } \\
1\end{array}$} & \multirow{2}{*}{$\begin{array}{c}\text { Business Competitive } \\
\text { Advantage } \\
.965^{* *}\end{array}$} \\
\hline \multirow{3}{*}{$\begin{array}{l}\text { Marketplace } \\
\text { Opportunity }\end{array}$} & Pearson Correlation & & \\
\hline & Sig. (2-tailed) & & .000 \\
\hline & $\mathrm{N}$ & 279 & 279 \\
\hline \multirow{3}{*}{$\begin{array}{l}\text { Business } \\
\text { Competitive } \\
\text { Advantage }\end{array}$} & Pearson Correlation & $.965^{* *}$ & 1 \\
\hline & Sig. (2-tailed) & .000 & \\
\hline & $\mathrm{N}$ & 279 & 279 \\
\hline
\end{tabular}


The table showed the result of the hypothesis stated above. To test the hypothesis, the Pearson correlation coefficient was carried out to show the influence of marketplace opportunity on business competitive advantage. The relationship between the two variables produced a positive correlation coefficient of $0.965^{* *}$ which depicts a strong direct correlation between marketplace opportunity and business competitive advantage. Also, the two tailed test conducted to check for the significance level of the value of correlation coefficient yields a P-value of 0.000 which was significant at 0.05 levels. Therefore, the hypothesis that, marketplace opportunity does not influence business competitive advantage was rejected, as the result implies that marketplace opportunity has significant influence on business competitive advantage.

\section{Hypothesis Four}

$\mathrm{HO}_{4}$ : Competitor's threat does not significantly influence business competitive advantage.

Tab. 5 - Relationship between Competitors' Threat and Business Competitive Advantage. Source: Research Study, 2016

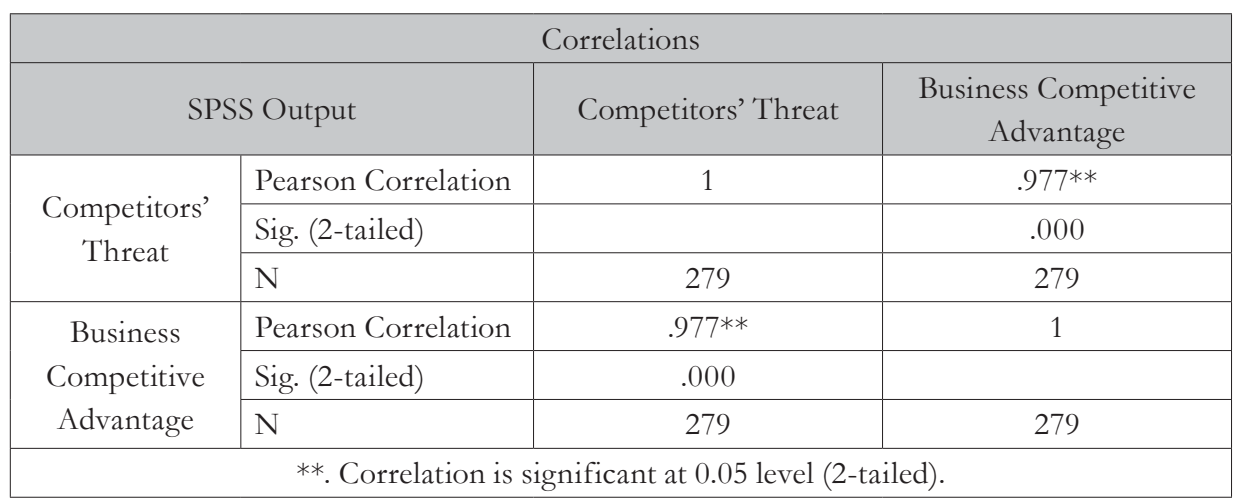

The above hypothesis was tested by the Pearson Product Moment correlation statistical tool. On this note, the relationship between two variables (competitors' threat and business competitive advantage) was found to be positive with a co-efficient of 0.977 a very strong relationship. Equally, the two tailed test conducted to check for the significance level of the value of correlation coefficient yields a P-value of 0.000 which was significant at 0.05 levels. Therefore, the hypothesis that states competitors' threat does not influence business competitive advantage was rejected, as the result implies that competitors' threat has a significant influence on business competitive advantage.

\section{Hypothesis Five}

$\mathrm{HO}_{5}$ : Competitive risk does not influence business competitive advantage. 
Tab. 6 - Relationship between Competitive Risk and Business Competitive Advantage.

Source: Research Study, 2016

\begin{tabular}{|c|c|c|c|}
\hline \multicolumn{4}{|c|}{ Correlations } \\
\hline \multicolumn{2}{|c|}{ SPSS Output } & \multirow{2}{*}{$\begin{array}{c}\text { Competitive Risk } \\
1\end{array}$} & \multirow{2}{*}{$\begin{array}{c}\text { Business Competitive } \\
\text { Advantage } \\
.959 * *\end{array}$} \\
\hline \multirow{3}{*}{$\begin{array}{c}\text { Competitive } \\
\text { Risk }\end{array}$} & Pearson Correlation & & \\
\hline & Sig. (2-tailed) & & .000 \\
\hline & $\mathrm{N}$ & 279 & 279 \\
\hline \multirow{3}{*}{$\begin{array}{l}\text { Business } \\
\text { Competitive } \\
\text { Advantage }\end{array}$} & Pearson Correlation & $.959 * *$ & 1 \\
\hline & Sig. (2-tailed) & .000 & \\
\hline & $\mathrm{N}$ & 279 & 279 \\
\hline
\end{tabular}

The table showed the result of the hypothesis stated above. To test the hypothesis, the Pearson correlation coefficient was carried out to show the influence of competitive risk on business competitive advantage. However, the relationship between the two variables produced a positive correlation coefficient of $0.959^{* *}$ which depicts a strong direct correlation between competitive risk and business competitive advantage. Also, the two tailed test conducted to check the significance level of the value of correlation coefficient yields a P-value of 0.000 which was significant at 0.05 level. Therefore, the hypothesis that state competitive risk does not influence business competitive advantage was rejected, as the result implies that competitive risk has significant influence on business competitive advantage.

\section{Regression Analysis}

To further test each of the hypotheses formulated in the study, a multiple regression analysis was conducted to confirm the presence of relationship between the constructs of the study. The regression analysis can be used to forecast the values of a dependent variable given value of one or more independent variables by calculation of a regression equation. Therefore, a general model of the regression analysis is given below;

$\mathrm{Y}=\mathrm{a}+\beta 1_{\mathrm{x} 1}+\beta 2_{\mathrm{x} 2}+\beta 3_{\mathrm{x} 3}+\beta 4_{\mathrm{x} 4}+\beta 5_{\mathrm{x} 5}$

Where:

$\mathrm{Y}=$ Dependent Variable

$\mathrm{a}=$ Regression Constant

$\beta=$ Beta coefficient or intercept or slope (i.e. explains the actual effect of the independent variable on dependent variable).

$\mathrm{X} n=$ The Changing Variables (i.e. $\mathrm{x}_{1}, \mathrm{x}_{2}, \mathrm{x}_{3}, \mathrm{x}_{4}, \mathrm{x}_{5}$ ) 
Tab.7 - Regression Model Summary and ANOVA to Forecast Marketing Intelligence Variables on Business Competitive Advantage. Source: Research Study, 2016

\begin{tabular}{|c|c|c|c|c|c|c|}
\hline \multicolumn{3}{|c|}{$\mathrm{R}=.981 \mathrm{a}$} & & & & \\
\hline \multicolumn{7}{|c|}{ R Square $=.963$} \\
\hline \multicolumn{7}{|c|}{ Adjusted R Square $=.962$} \\
\hline \multicolumn{7}{|c|}{ Standard Error $=.06982$} \\
\hline Model & $\begin{array}{l}\text { Sum of } \\
\text { Squares }\end{array}$ & Df & $\begin{array}{l}\text { Mean } \\
\text { Square }\end{array}$ & $\mathrm{F}$ & Sig. & \\
\hline \multirow[t]{3}{*}{1} & Regression & 34.420 & 5 & 6.884 & 1412.319 & $.000 \mathrm{~b}$ \\
\hline & Residual & 1.331 & 273 & .005 & & \\
\hline & Total & 35.751 & 278 & & & \\
\hline
\end{tabular}

The regression ANOVA table above shows that the observed variance accounted for by five predictors (internal records, competitors' sales data, marketplace opportunity, competitors' threat and competitive risk) is $96.3 \%$. This connotes a strong and positive relationship between marketing intelligence and business competitive advantage which also confirm the previously tested correlation result of five sub-constructs of marketing intelligence on business competitive advantage. The F-ratio is statistically significant as $\mathrm{F}(5,273)=1,412.319, \mathrm{P}(0.000)<0.05$. This means that the five predictors jointly contribute to the observed change in the dependent variable (business competitive advantage).

Tab. 8 - Coefficient Table for Marketing Intelligence and Business Competitive Advantage Source: Research Study, 2016

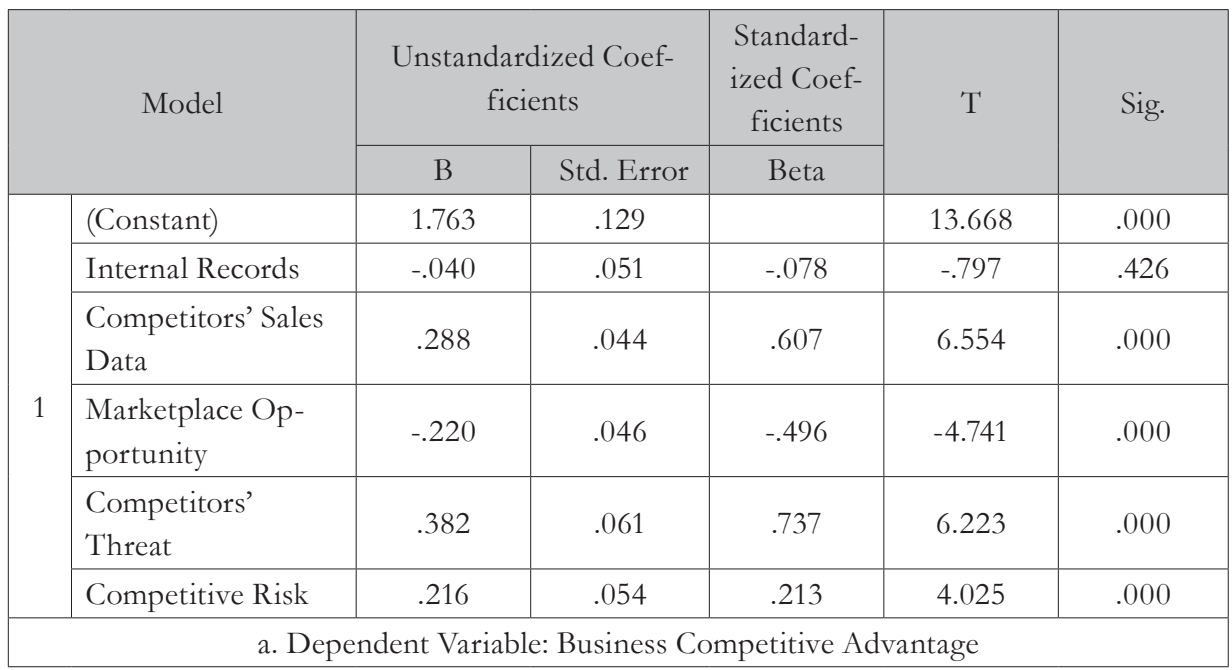

Table 8 shows that four out of five predictor variables contribute significantly to business competitive advantage. It is evident from the table that Competitors' sales data: $\beta=.607$; $\mathrm{t}(279)=$ 6.554, $\mathrm{P}(.000)<0.05$; Marketplace opportunity: $\beta=-.496 ; \mathrm{t}(279)=-4.741, \mathrm{P}(.000)<0.05$; 
Competitors' threat: $\beta=.737$; $(279)=6.223, \mathrm{P}(.000)<0.05$ and Competitive risk: $\beta=.213$; $\mathrm{t}$ $(279)=4.025, \mathrm{P}(.000)<0.05$ contributes more significantly to business competitive advantage. However, internal records: $\beta=.078$; $\mathrm{t}(279)=-0.797, \mathrm{P}(.000)<0.05$ were not significant. This implies that for every unit change in business competitive advantage, there is a corresponding increase of .607, .737 and .213 from competitors' sales data, competitors' threat and competitive risk respectively, as marketplace opportunity and internal records' inversely contributed by -.496 and -.078 respectively. Thus, from the table, the regression equation is given below:

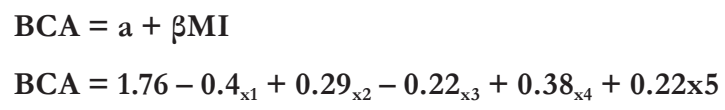

Where:

$\mathrm{BCA}=$ Business Competitive Advantage

$\mathrm{a}=$ Regression Constant

$\beta=$ Beta coefficient or interception or slope

$\mathrm{MI}=$ Marketing Intelligence

$\mathrm{X}_{1}=$ Internal Records

$\mathrm{X}_{2}=$ Competitors' Sales Data

$\mathrm{X}_{3}=$ Marketplace Opportunity

$\mathrm{X}_{4}=$ Competitors' Threat

$\mathrm{X}_{5}=$ Competitive Risk

Therefore, the summarized regression equation showed above reveals the test of relationship between marketing intelligence (independent variable) and business competitive advantage (dependent variable). The table reveals that there is a high level of fitness at $\mathrm{R}$ value of $0.981, \mathrm{R}^{2}$ of 0.963 and $\mathrm{F}$-value of $1,412.319$. The $\mathrm{R}^{2}$ of 0.963 connotes that about $96.3 \%$ of the variation in business competitive advantage can be explained by the sub-constructs of marketing intelligence, such as internal records, competitors' sales data, marketplace opportunity, competitors' threat and competitive risk, while $3.7 \%$ remain unexplained by the regression model. However, the $R$ value of 0.981 in the table indicates that a strong and positive relationship is found between the two variables (i.e. marketing intelligence and business competitive advantage), which also helps to confirm the correlation results obtained from the test of the previously tested five (5) hypotheses. Since the F-sig. (p-value) of .000 is less than $\alpha(0.05)$, it was found that there was a significant influence of marketing intelligence on business competitive advantage, as the variation explained by the regression model is not by chance.

\section{DISCUSSION OF FINDINGS}

With regards to the hypothesis one which states that there is no significant relationship between internal record and business competitive advantage, the study discovered that internal record is significantly related to business competitive advantage. This result is similar to the findings of Freihat (2012) and Alhadid et al (2015) which reveals that there is a statistically significant 
relationship "between internal records, marketing research, marketing intelligence and decisionmaking".

Also, the second hypothesis which states that there is no significant relationship between competitor's sales data and business competitive advantage, the study found out that competitor's sales data is significantly related to business competitive advantage. This result is line with the findings of Hakkak and Ghodsi (2015) which indicated that there is a significant and positive impact of the implementation of the competitors' sales record and balanced scorecard on the sustainable competitive advantage.

Furthermore, with respect to the third hypothesis which states that marketplace opportunity does not influence business competitive advantage, the result shows that a marketplace opportunity has a significant influence on business competitive advantage. This result is corroborated with the findings of Venter and Rensburg (2014) which revealed that the availability of marketplace opportunity and intelligence (intelligence on customers, competitors and suppliers) has the greatest direct effect on perception of the overall quality of marketing intelligence and perhaps plays a mediating role, given its strong relationships with other categories of marketing intelligence.

However, as touching the fourth hypothesis which states that competitors' threat does not influence business competitive advantage, the study discovered that competitors' threat has a significant influence on business competitive advantage. And the finding of the last hypothesis indicates that competitive risk has significant influence on business competitive advantage, which negates the null hypothesis which states that competitive risk does not influence business competitive advantage. However, both competitors' threat and competitive risk as indicated by Nwokah and Onduku (2009) are significantly related to "customer philosophy, integrated marketing efforts, marketing information, strategy orientation and organisations operational efficiency in a competitive environment".

Finally, the regression analysis shows that the observed variance accounted for by the five subconstructs (internal records, competitors' sales data, marketplace opportunity, competitors' threat and competitive risk) jointly contribute to the observed change in the dependent variable (business competitive advantage). Also, the result of the R 2 of 0.963 from the findings connotes that about $96.3 \%$ of the variation in business competitive advantage can be explained by the subconstructs of marketing intelligence, such as internal records, competitors' sales data, marketplace opportunity, competitors' threat and competitive risk, as the $\mathrm{R}$ value of 0.981 indicates that a strong and positive relationship is found between the two variables (i.e. marketing intelligence and business competitive advantage).

Therefore, since the F-sig. (p-value) of .000 is less than $\alpha(0.05)$, hence, a significant correlation is found between marketing intelligence and business competitive advantage. This result is supported in the findings of Queiroz, \& Oliveira (2014) which indicated that marketing intelligence and the systematization of information in the market settings "possess great importance for the development of competitiveness, contributing to development of the operations and to promotion of new business opportunities". 


\section{CONCLUSION}

Marketing intelligence is considered a vital instrument for an organization that aims to survive in the marketplace and has business competitive advantage. Thus, "marketing intelligence is the systematic collection and analysis of publicly available information about consumers, competitors, and developments in the marketplace" (Kotler \& Armstrong, 2013). However, the purpose and objective of this study was to establish the influence of marketing intelligence on business competitive advantage with reference to Diamond Bank Plc. According to the result from the findings, there is a significant relationship between all the sub-constructs of marketing intelligence, such as internal records, competitors' sales data, marketplace opportunity, competitors' threat and competitive risk on business competitive advantage.

Also, the result of the multiple regression analysis reveals that $96.3 \%$ of the variation in business competitive advantage can be explained by the sub-constructs of marketing intelligence, such as internal records, competitors' sales data, marketplace opportunity, competitors' threat and competitive risk, as the $\mathrm{R}$ value of 0.981 indicates that a strong and positive influence is found between marketing intelligence and business competitive advantage. Therefore, above average returns can be maintained if a company gains business competitive advantage over time in the market, and all these are attributed to the amount of market information and intelligence a company can gather, store and utilize to the best of its advantage. Such information and marketing intelligence had enabled the bank to successfully acquire more profit, expand its branch network, perform better than its rivals in the market and increase its competitive advantage.

\section{RECOMMENDATIONS}

In the light of this study, the following recommendations are made so as to help the bank to enhance its operation and be of great value to the firms. Firstly, it is recommended that the management of firms should thus take keen interest in safe keeping all items of information about the operation system, sales data, core competence and other strategies including their strength, weakness, opportunities and threat. Also, organizations should prioritize and be proactive in information collection pertaining to daily marketing activities to best support their business at low cost as internal record may not necessarily contribute to business competitive advantage at the long run. Secondly, competitors' sales data as one of the components of "marketing intelligence represents a continuous process of understanding, analyzing, and assessing the internal and external environments associated with competitors"(Alamsyah, Rahmah, \&Irawan, 2015)and markets at large and then using the information acquired to enhance firms thorough operations. Thus, competitor's sales data should serve as an instrument which reveals the competitors' weaknesses and encourages the firms to utilize the opportunity towards increasing the organization performance as well as profitability. Thirdly, marketplace opportunity as a factor is important to firms that develop strategies and intend to outwit rivals by sustaining competitive advantage. Due to its inverse relationship with the business competitive advantage as the findings revealed, it is recommended that firms should reduce the cost of identifying market opportunities which may negatively contribute to business competitive advantage in the long run. This will help to avoid excessive cost on futile strategies and increase organizational profitability. Also, firms 
should have an avenue or programs in the organization to deliberately plan on how competitors' threats can be neutralized, through regular and continuous scanning of the external environment and identifying major threat that may serve as an antagonism to the company in the marketplace. The study also recommends that firms should frequently measure or assess the risk of competing in a particular market, under which information should be gathered and proper market research should be conducted towards assessing the implications of competing head to head with major competitors in the marketplace.

Finally, information is a very crucial and sensitive tool that is useful for external bodies in competitive environment. This has caused a lot of hackers' sleepless night and timely stress to break and unlock organizations database in order for them to assess both the organization and their customers' information. Meanwhile, customers' negligence sometimes handles their account information and passwords with levity under un-trusted sites and gadgets which helps the hackers' to easily assess such accounts. Therefore, firms should recruit and train specialists in information technology (IT) popularly known as anti-hackers or hack gurus to protect their internal database from getting hacked, whilst customers should as well base the assessment of their accounts and information on reliable gadgets and software such as Apple Mac Cloud, Google Drive, Kaspersky and others to run their transactions and avoid third-party access to their personal accounts.

\section{SUGGESTION FOR FURTHER STUDIES}

As an attempt to complement and enrich this study, it is suggested for future studies to conduct and compare the level, flows and usefulness of marketing intelligence among existing firms in Nigeria regardless of their regions, state headquarters and country wide towards achieving business competitive edge over each other in the marketplace. Also, for future research, attention should be paid to the variation in the sub-constructs of marketing intelligence, most especially internal record and marketplace opportunity with inverse relationship with the business competitive advantage.

\section{References}

1. Alamsyah, A., Rahmah, W., \&Irawan, H. (2015).Sentiment analysis based on appraisal theory for marketing intelligence in Indonesia's mobile phone market. Journal of Theoretical and Applied Information Technology, 82(2), 1-6.

2. Alhadid, Y., Al-Zu'bi, H., \&Samer, B. (2015).The relationship between marketing information system and gaining competitive advantage in the banking sector in Jordan. European Journal of Scientific Research, 128(1), 35-44.

3. Bowley, A. L. (1926). Measurements of precision attained in sampling. Bulleting of the International Statistics Institute, Amsterdam, 22(1), 1-62.

4. Chern, C., Anthony, J., \&Chih-Ping, W. (2014).Introduction to the special issue on "Data analytics for marketing intelligence", Information Systems and e-Business Management.

5. Crocker, J. (1984). A schematic approach to changing consumers' beliefs. Association for Consumer Research, 11(3), 472-477. 
6. Dixon-Ogbechi, B. N. (2002). Research methods and elementary statistic in practice. Lagos: Philglad Nigeria Limited.

7. Fahey, L. (2007). Connecting strategy and competitive intelligence: Refocusing intelligence to produce critical strategy inputs. Strategy Leadership Journal, 35(1), 4-12.

8. Freihat, S. M. (2012). The role of marketing information system in marketing decisionmaking in Jordanian shareholding medicines production companies .International Journal of Research and Review in Applied Science, 11(2), 1-11.

9. Hakkak, M., \&Ghodsi, M. (2015). Development of a sustainable competitive advantage model based on balanced scorecard. International Journal of Asian Social Science, 5(5), 298-308.

10. Igbaekemen, G. O. (2014). Marketing intelligence as a strategic tool for competitive edge. British Journal of Marketing Studies, 2(5), 17-34.

11. Johns, P., \& Van Doren, D. (2010). Competitive intelligence in service marketing: a new approach with practical application, marketing intelligence \& planning. European Journal of Marketing, 28(5), 13-19.

12. Kotler, P., \& Armstrong, G. (2013).Principles of marketing .Edinburgh Gate: Pearson Education Limited.

13. McDaniel, S. R. (1999). An investigation of match-up effects in sport sponsorship advertising: The implications of consumer advertising schemas. Journal of Psychology \& Marketing, 16(3), 163-184.

14. Nwokah, N. G. \&Onduku, F. E. (2009).Competitive intelligence and marketing effectiveness in corporate organisations in Nigeria. African Journal of Marketing Management, $1(1), 10-22$.

15. Pallant, J. (2001). SPSS survival manual. Milton Keynes: Open University Press.

16. Porter, M. (1980).Competitive strategy: Techniques for analyzing industries and competitors. New York: The Free Press.

17. Priem, R., \& Butler, J. (2001). Is the resource-based view a useful perspective for strategic management research? Academy of Management Review, 26(1), 22-40.

18. Queiroz, J., \& Oliveira, B. (2014).benefits of the marketing information system in the clothing retail business. Journal of Information Systems and Technology Management, 11(1), 153-168.

19. Ray, M. L., Ochsner, K. N., Cooper, J. C., Robertson, E. R., Chopra, S., Gabrieli, J. D., \& Gross, J. J. (2004). For better or for worse: Neural systems supporting the cognitive down and up regulation of negative emotion. Neuro Image, 23(2), 483-499.

20. Speck, W., Surgi, P., David, W., Schumann, H., \& Thompson, C. (1988). Celebrity endorsements: Scripts, schema and roles: Theoretical framework and preliminary tests. Advances in Consumer Research, 15(3), 69-76.

21. Tan, T. W., \& Ahmad, Z. U. (1999). Managing marketing intelligence: An Asian marketing research perspective. Journal of Marketing Intelligence \& Planning, 17(6), 298-306.

22. Venter, P., \&Rensburg, M. (2014).The relationship between marketing intelligence and strategic marketing. UNIS A Graduate School of Business Leadership, 17(4), 440-456. 
23. Wernerfelt, B. (1984). A resource-based view of the firm .Strategic Management Journal, 5(2), 171-180.

24. Yamane,T.(1967).Statistics: An introductory analysis. New York: Harper and Ro

\section{Contact information}

Dr. Patrick, K. A. Ladipo (PhD)

Department of Business Administration

University of Lagos

Akoka, Yaba, Lagos, Nigeria.

Email:pkaladipo@yahoo.com

Dr. Mufutau Akanbi Awoniyi (PhD)

Department of Marketing

Lagos State University

Ojo, Lagos, Nigeria.

Email:mugafric2001@yahoo.com

Ismail Tubosun Arebi

Department of Business Administration

University of Lagos

Akoka, Yaba, Lagos, Nigeria.

Email:arebi.ismail@gmail.com 